\title{
Immobilization of Vigna Radiata $\beta$ amylase onto sodium nitrate treated and chlorinated woven Bombyx mori silk fabric
}

\author{
${ }^{* 1}$ Kirti Rani, ${ }^{1}$ Krishna Jemamoni \\ ${ }^{1}$ Amity Institute of Biotechnology, Amity University Uttar Pradesh, Noida (UP), India
}

\begin{abstract}
Vigna radiata $\beta$-amylase was immobilized onto activated woven Bombyx mori silk fabric with glutaraldehyde and amino groups enrichment made by chlorination and by treatment with sodium nitrate $\left(\mathrm{NaNO}_{3}\right)$. The immobilization of enzyme onto sodium nitrate treated and chlorinated woven Bombyx mori silk fabric was excellent by having $90 \%$ of retention of enzyme activity after the immobilization. The optimum conditions of immobilized enzyme were studied such as time of incubation, $\mathrm{pH}$, temperature, substrate concentration and $\mathrm{CaCl}_{2}$ concentration. Thermal stability of the enzyme was improved after immobilization which was $72^{\circ} \mathrm{C}$ as compared to free enzyme which was only $40^{\circ} \mathrm{C}$. In addition, the immobilized enzyme has good storage stability and reusability by maintaining $60 \%$ of its activity up to $3-4$ months.
\end{abstract}

Keywords: Vigna radiata, $\beta$-Amylase, glutaraldehyde, immobilization and Bombyx mori silk fabric.

\section{INTRODUCTION}

$\beta$-Amylase (1,4- $\alpha$-D-Glucan maltohydrolase; EC 3.2.1.2) plays a central role in the complete degradation of starch to metabolisable or fermentable sugars during the germination or malting of cereal grains (Okamoto, K. and Kitano, H., 1980). It also finds considerable application, together with starch de-branching enzymes, in the production of high maltose syrups. $\beta$-Amylase is usually measured using non-specific reducing sugar assays with starch as substrate. In some methods, the a-amylase is first inactivated by treatment at low $\mathrm{pH}$. $\beta$-Amylase is more selective than alpha-amylase since it breaks off two sugars at a time from the starch chain. $\beta$-Amylases are present in yeasts, molds, bacteria, and plants, particularly in the seeds. They are the principal components of a mixture called diastase that is used in the removal of starchy sizing agents from textiles and in the conversion of cereal grains to fermentable sugars. Starch consists of two components: amylose and amylopectin. The relative proportion of these two components varies, and they react differently to enzymatic attack. The enzyme $\beta$-Amylase (maltogenic) attacks the straight chain amylose but is unable to attack most of the branch chain amylopectin. $\beta$-Amylase, ubiquitous in nature, have been isolated, purified and characterized from a number of animal, plant, fungal, as well as bacterial sources. The $\beta$-Amylase is calcium metallo-enzymes, many times completely unable to function in the absence of calcium. Amylase is instrumental in starch digestion in animals resulting in the formation of sugars, which are subsequently used in various metabolic activities (Greenwood et al., 1975). The site of amylase synthesis is reported to be either in aleurone layer or scutellum. The aim of the present work is to extract $\beta$-Amylase enzyme from germinated Vigna radiata (Family: Leguminosae). In the characterization of crude extract, various aspects of study include determining the $\mathrm{pH}$ optima for activity and stability, temperature optima for activity and stability, effect of $\mathrm{CaCl}_{2}$ on enzymatic activity and optimum substrate concentration. Fibrous silk has a large surface area, high mechanical strength and good compatibility which are advantageous to the use as a support for the enzyme immobilization (Grasset, et al., 1977, 1979 \& Komatsu, 1989). Silk fibers in the form of woven fabric were used as a novel and inexpensive carrier for the immobilization of lipase from Candida sp (Biqiang Chen, et al., 2010). Silk biomaterials are biocompatible and can be chemically modified through amino acid side chains to alter surface properties for immobilizing the cellular growth factors (Charu Vepari and David L. Kaplan, 2007). The amino group enrichment of Bombyx mori silk fabric was made by the treatment of chlorinated silk fabric with 2aminoethanethiol (AET) and poly(ethylenimine) (PEI) (Furuhata, et al., 1996 and ${ }^{3}$ Rani, K., 2012). The amount of amino groups introduced into silk fabrics by these treatments were more than 10 times as much as that of untreated silk fabrics which plays an important role in immobilization. Although the method of immobilization of amylase onto Bombyx mori silk fibroin are available such as immobilized was by covalent bond formation by diazo and cyanogen bromide (Myrbrack, K. and Neumuller G., 1950), onto partially hydrolyzed silk fabrics by using diazo, adsorption, glutaraledyde and azide methods (Grasset, et al ., 1983). As well as the other enzymes such as glucose oxidase (GOD) was immobilized on the nonwoven fabrics with Bombyx mori silk fibroin gel, viscose rayon, poly-ethyleneterephthalate, 6-nylon, and polypropylene with activated surface by fluoline treatment (Myrbrack., et al., 1991). Other medically important enzymes such as 3- $\alpha$ hydroxysteroid dehydrogenase and diaphorase were immobilized onto inorganic supports rather than the onto Bombyx mori silk fibroin such as alkylamine glass beads through covalent coupling $\left({ }^{2}\right.$ Rani et al., 2006) and onto arylamine glass beads through diazotization ( ${ }^{1}$ Rani, K. et al., 2004). However, all these methods were expensive methods as it required tedious 
techniques for activation of organic and inorganic matrices and required costly equipments as well as commercial prepared enzymes too. But, in the present work, we described the immobilization of $\beta$-amylase which was extracted from Vigna radiata onto nitrated and chlorinated woven Bombyx mori silk fabric through covalent coupling with glutraraldehyde. The kinetic properties of immobilized enzyme were also studied. Woven Bombyx mori silk fabrics have excellent properties in diffusivity of substrates, mechanical strength, and handling as well as Vigna radiatais itself a rich \& cheap source of amylase. In the present report, we describe the covalent coupling of amylase with chlorine molecules and this coupling suppresses or prevents the thermal denaturation as well as the bound enzyme becomes more resistant to fungal and bacterial attack by increasing thermal stability and storage stability which will be advantageous tool for practical use. ( ${ }^{3}$ Rani K et al., 2012).

\section{Materials and Methods}

Bombyx mori silk were chlorinated with $\mathrm{NaCl}$ solution (chlorine content, 3\%) and then treated with sodium nitrate and glutraldehyde according to the procedure reported previously (Furuhata, et al.,1996 and ${ }^{3}$ Rani, K., 2012). Amylase was extracted and purified from Vigna radiata Glutraldehyde (GA), sodium nitrate, $\mathrm{NaCl}$ and other chemicals were of analytical grade.

\subsection{Preparation of Crude Extract}

$20 \mathrm{gm}$ sprouted mung beans (Vigna radiata) were homogenized at $0-4^{\circ} \mathrm{C}$ in $0.05 \mathrm{M}$ potassium phosphate buffer ( $\mathrm{pH}-$ 7) and centrifuged at $8000 \mathrm{rpm}$ for 15 minutes. Supernatant was collected which contained enzyme and the specific activity was measured by dinitrosalicylic acid method (Bernfeld et al ., 1951) and stored at $4^{\circ} \mathrm{C}$.

\subsection{Enzyme Assay}

Amylase activity was measured spectrophotometrically by incubating immobilized enzyme (GA-treated woven Bombyx mori silk fabric) with $2.0 \mathrm{ml}$ of 3,5-dinitrosalicylic acid (prepared in $50 \mathrm{ml}$ reagent grade water) at $37^{\circ} \mathrm{C}$ for 2 minutes and after that $2 \mathrm{ml}$ of DNS was added to terminate the reaction and the reaction mixture was boiled at $100^{\circ} \mathrm{C}$ for 5 minutes. Hence, the measurement of concentration of maltose which was liberated from starch on by $\beta$-amylase during reaction was read at 570nm (Bernfeld et al., 1951). One unit of enzyme was equal to release of one micromole of $\beta$-maltose per min at $25^{\circ} \mathrm{C}$ under the specified conditions.

\subsection{Immobilization of Vigna radiata $\beta$-Amylase onto nitrated-chlorinated woven Bombyx mori silk fabric}

Glutaraldehyde treatment: Pieces of sodium nitrate and chlorine treated woven Bombyx mori silk fabric (10-15 mg) were treated with $10 \%$ GA solution in an incubator at $37^{\circ} \mathrm{C}$ for 1 hour at liquor ratio of $100-200$. After the treatment, the sample pieces were washed repeatedly with distilled water for 6-8 hours after an interval of $30 \mathrm{~min}$.

\subsection{Immobilization of Vigna radiata $\beta$-Amylase}

Pieces of GA-treated woven Bombyx mori silk fabric (10-15mg) were put into a flask and $5 \mathrm{ml}$ solution of an amylase $(1 \mathrm{mg} / \mathrm{ml})$ was added. The flask was kept at $37^{\circ} \mathrm{C}$ for 24 hours with occasional stirring. After the treatment, the fabric pieces were taken out and the remaining solution was analyzed by dintitosalicylic acid method to estimate the residual enzyme activity. The treated fabric pieces were washed several times with $1 \mathrm{M} \mathrm{KCL}$ for 2 hours at $30^{\circ} \mathrm{C}$ under shaking in incubator. These were stored in a refrigerator at $4^{\circ} \mathrm{C}$ in $0.1 \mathrm{M} \mathrm{KCL}$ solution.

\section{5. \% Retention of enzyme activity}

The enzyme bound to sodium nitrate-treated chlorinated woven Bombyx mori silk fabric was estimated by determining the residual specific activity from solution of enzyme during immobilization by determining its residual activity by dinitrosalicylic acid method which was determined as follows:

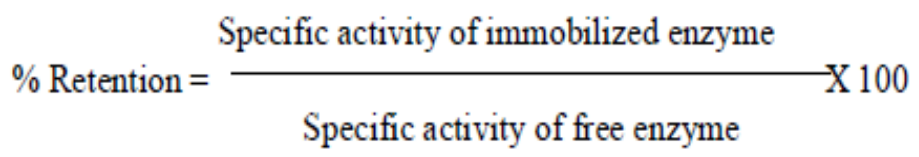

\subsection{Characterization}

The enzyme was characterized for its various kinetic properties i.e. effect of time of incubation, $\mathrm{pH}$, temperature, substrate concentration and $\mathrm{CaCl}_{2}$ concentration.

\subsubsection{Effect of incubation time}

The effect of incubation time on the activity of the enzyme was studied by performing the enzyme assay at different time (5min-25min) with an interval of 5 min and carrying out the enzyme activity by dinitrosalicylic acid method. 


\subsubsection{Effect of pH}

The effect of $\mathrm{pH}$ on activity of the enzyme was studied by performing the enzyme assay at different $\mathrm{pH}$ using acetate buffer, phosphate buffer and carbonate buffer ( $\mathrm{pH}$ rang of 2.5-10.5), the optimum $\mathrm{pH}$ of the enzyme was determined by incubating the enzyme with varying of buffer described above and then carried out the enzyme activity by dinitrosalicylic acid method.

\subsubsection{Effect of temperature}

Optimal temperature needed for enzyme activity was estimated by incubating the reaction mixture at different temperature $\left(20^{\circ} \mathrm{C}-80^{\circ} \mathrm{C}\right)$ by dinitrosalicylic acid method.

\subsubsection{Effect of substrate concentration}

Optimal substrate concentration needed for enzyme activity was estimated by incubating the reaction mixture for 15 minutes at different concentrations of starch solution $(0.25 \%-1.75 \%)$ by dinitrosalicylic acid method.

\subsubsection{Effect of $\mathrm{CaCl}_{2}$}

The effect of $\mathrm{CaCl} 2$ on activity of the enzyme was studied by performing the enzyme assay at different $\mathrm{CaCl} 2$ concentrations $(2 \%-8 \%)$ by dinitrosalicylic acid method.

\section{RESULT}

\section{1. \% Retention of enzyme activity}

Our present study was reported 90\% immobilization onto nitrated and chlorinated woven Bombyx mori silk fabric which showed that maximum activity and stability of amylase after immobilization due to having good conformational stability as compared to free enzyme.

\subsection{Effect of incubation time}

The reaction mixture of immobilized and free amylase was incubated for varied time intervals from 5 to 25 minutes and optimum incubation time was 20 minutes (Figure 1). Our present study was showed that incubation time of immobilized enzyme was same as that of free enzyme (20min).

\subsection{Effect of $\mathrm{pH}$}

The $\mathrm{pH}$ of the reaction mixture of immobilized and free enzyme was varied from 2.5 to 10.5 as shown in Figure 2. A distinct peak corresponding to optimum pH 5.5 was obtained indicating that optimum $\mathrm{pH}$ was similar to free enzyme. Hence, there was no change in $\mathrm{pH}$ on immobilized enzyme activity.

\subsection{Effect of temperature}

Optimum temperature of immobilized and free enzyme was determined by various temperatures from $20^{\circ} \mathrm{C}$ to $80^{\circ} \mathrm{C}$. The enzyme was found to show maximum activity and thermal stability at $72^{\circ} \mathrm{C}$ as shown in Figure 3 . The present study was showed thermal stability at $72^{\circ} \mathrm{C}$ which was higher than that to free enzyme $\left(40^{\circ} \mathrm{C}\right)$

\subsection{Effect of Substrate Concentration}

The starch concentration was varied from 0.25 to 1.75 as shown in Figure 4. There is no change in substrate concentration on immobilized enzyme activity.

\subsection{Effect of $\mathrm{CaCl}_{2}$}

The reaction mixture of immobilized and free enzyme was incubated for varied $\mathrm{CaCl}_{2}$ concentration. The $6 \%$ of $\mathrm{CaCl}_{2}$ concentration was found optimum (Figure 5). Our present study was showed that beyond $6 \% \mathrm{CaCl}_{2}$ concentration, the enzyme activity was decreased which was higher than that of free enzyme (4\%).

\section{DISCUSSION}

\subsection{Effect of incubation time}

Optimum incubation time of immobilized enzyme is same as that of free enzyme (20min) as well as to similar to earlier report which was 15 min (Lopez, F., et al., 1997 and ${ }^{4}$ Rani, K., 2012).

\subsection{Effect of $\mathrm{pH}$}

The obtained optimum $\mathrm{pH}$ was 5.5 which similar to free enzyme and previous findings too (Quinn, Z., et al., 2001 and ${ }^{4}$ Rani, K., 2012). There is no change in $\mathrm{pH}$ after immobilization.

\subsection{Effect of temperature}

The immobilized enzyme had maximum activity as well as thermal stability at around $72^{\circ} \mathrm{C}$ as shown in Figure 3 .

The immobilization of the enzyme has certainly increased the optimum temperature and thermal stability of the enzyme which was confirmed from the current study. Immobilization can provide increased resistance to changes in conditions such as $\mathrm{pH}$ or temperature and it was comparable to previous reports (Lopez, F. et al., 1997 and ${ }^{4}$ Rani, K., 2012).

\subsection{Effect of Substrate Concentration}

Due to immobilization, the starch degradation activity of the enzyme remained the same as of the free enzyme. 


\subsection{Effect of $\mathrm{CaCl}_{2}$}

There was not too much change in $\mathrm{CaCl}_{2}$ concentration which was of $6 \%$. This optimum $\mathrm{CaCl}_{2}$ concentration was pretty similar to that of the free enzyme as well as earlier reports too which confirmed that beyond $6 \%$, the activity of immobilized enzymes was decreased due to deleterious effect of calcium ions (Rodriguez, C., et al., 1993).

\subsection{Storage stability and reusability}

The immobilized amylase lost only $40 \%$ of its activity after 3-4 months, when stored in $0.1 \mathrm{M} \mathrm{KCL}$ solution at $0^{\circ} \mathrm{C}$ to $4^{\circ} \mathrm{C}$ (Table 1) which was pretty good as compared to earlier report which was only for 15 days (Errikson, J., et al., 1997). The present study shows that increased storage stability as well as reusability after the immobilization on to activated Bombyx mori silk fabric $\left({ }^{3}\right.$ Rani, K., 2012).

\section{Conclusion}

The figure 3 was showed shows maximal thermal stability of immobilized Vigna radiata $\beta$-amylase at $72^{\circ} \mathrm{C}$ as well as the time of incubation was $20 \mathrm{~min}$ at $\mathrm{pH}$ 5.5. The maximal specific activity of Vigna radiata $\beta$-amylase onto glutraldehyde treated silk fabric is remarkable and having $90 \%$ of retention of enzyme activity onto activated fabric after immobilization due to the attainment of good conformational stability. (Joaquim., et al ., 1991 and ${ }^{1}$ Rani, K., 2012). Enzyme molecules was coupled with chlorine molecules and nito groups after the treatment of sodium chloride and sodium nitrate through covalent coupling by glutaraldehyde suppressed the thermal denaturation as well as more increase the resistant towards fungal and bacterial attack too $\left({ }^{3}\right.$ Rani, K, 2012, ${ }^{2}$ Rani, K. et al., 2006 and ${ }^{1}$ Rani, K. et al., 2004). Thus, increased thermal stability, storage stability and reusability of immobilized enzyme will be advantageous to practical use (Lopez, F., et al., 1997, ${ }^{3}$ Rani, K, 2012, ${ }^{2}$ Rani, K. et al., 2006 and ${ }^{1}$ Rani, K. et al., 2004).

\section{REFERENCES}

[1]. Asakura, T., Kanetake, J. and Demura, M. Preparation and properties of covalently immobilized amylase on Bombyx mori silk fibroin fiber. Polym.-Plast. Technol. Eng. 28, 1989, 453-469.

[2]. Banks W, Greenwood.Starch and its components. Edinberg University Press (1975).

[3]. Bernfeld, P. Enzymes of starch degradation and synthesis. Advances in enzymology. (1951), 379-481.

[4]. Bickerstaff, G.F., Ed. Immobilization of Enzymes and Cells, Totowa, N.J.: Humana Press, (1997).

[5]. Biqiang Chena, b., Chunhua Yinc, Yuanyuan Chenga, Weina Lia, Zhu-an Caob and Tianwei Tana. Using silk woven fabric as support for lipase immobilization: The effect of surface hydrophilicity/hydrophobicity on enzymatic activity and stability. Biomass and Bioenergy. 8, 2010, 33.

[6]. Cao, L. Immobilized enzymes: science or art. Curr Opinion Chem Biol. 9, 2005, 217-226.

[7]. Charu Vepari and David L. Kaplan: Silk as a Biomaterial..Prog Polym Sci.; 32(8-9), 2007, 991-1007.

[8]. Chibata, I., ed.: Koteika Seitei Shokubai (Immobilzed Biocatalysts), Chap. 3, Kodansha, (1991).

[9]. Fernandez-Lafuente, R., Rosell, C.M., Rodriguez, V. \& Guisan. Strategies for enzyme stabilization by intramolecular crosslinking with bifunctional reagents, Enz Microbial Tech, 17, 1995, 517-523.

[10]. Furuhata, K., Deno, S., Yamauchi, T and Sakamoto, M: Introduction of amino groups into silk. J.Seric.Sci.Jpn., 65, 1996, 319-325.

[11]. Graasset, L., Cordier, D. \& Ville. A. Woven silk as a carrier for the immobilization of enzyme. Biotech. Bioeng. 19 (6),1977, 1618.

[12]. Graasset, L., Cordier, D. \& Ville, A. Silk: A natural protein for enzyme immobilization. Process Bioochem., 14, 1979, 2-5.

[13]. Grasset, L., Cordier, D. Couturier, L., Ville, A., Immobilization of amylase on silk using diazo, adsorption, glutaradehyde, and azide methods: Optimum pH and properties of the conjugates, Biotechnob Bioeng., 25, 1983, 1423- 1434.

[14]. Golander, C.G., Eriksson, J.C. ESCA studies of the adsorption of polyethyleneimine and glutaraldehydereacted polyethyleneimine on polyethylene and mica surface. J. Colloid \& Interface Sc. 119, 1987, 38-48.

[15]. Hirabayashi, K; Development of silk utilization. Silk news of Japan. 1993- I O-27(236 I ).

[16]. Joaquim, M.S.C. \& Michael, P.C. Covalent and coordination immobilization of proteins, in: R. F.Taylor (Ed.) Protein immobilization, fundamentals and applications, Marcel Dekker, Inc, New York, 1991.

[17]. Katchalski-Katzir, E.,. Kraemer, D.M and Eupergit(R) C, a carrier for immobilization of enzymes of industrial potential. J. Mol Catalysis B: Enz. 10, 2000, 157-176.

[18]. Lopez-Gallego, F., Montes, T., Fuentes, M., Alonso, N., Grazu, V., Betancor, L., Guisan, J.M. and Fernandez-Lafuente, R. Improved stabilization of chemically aminated enzymes via multipoint covalent attachment on glyoxyl supports, Journal of Biotechnology, 116 (2005) 1-10.

[19]. MyrbrackK, Neumuller G. in Sumner, JB, Myrbrack K (eds). The enzyme : chemistry and mechanisms of action Vol.1 Academic Press, New York (1950). 
[20]. Okamoto, K., H. Kitano, T. Akazawa, Biosynthesis and excretion of hydrolases in germinating cereal seeds. Plant Cell Physiol. 1980; 201-204.

[21]. Okamoto, K., T. Akazawa,. Enzymic mechanisms of starch breakdown in germinating rice seeds. Amylase formation in the epithelium. Plant Physiol. 1979; 337-340.

[22]. Quinn Z. K. \& Xiao Dong, C. Effects of temperature and pH on the catalytic activity of the immobilized [beta]-amylase Glycine max. Biochem. Engg. J. 9, 2001, 33-40.

[23]. $\quad{ }^{1}$ Rani, K., Garg, P. and Pundir C.S. Measurement of bile acid with arylamine glass bound $3 \alpha$-hydroxysteriod dehydrogenase and diaphorase. Anal. Biochem. 332, 2004, 32-37.

[24]. $\quad{ }^{2}$ Rani, K., Garg, P. and Pundir, C.S. Discrete analysis of bile aicd in serum and bile with $3 \alpha$-hydroxysteroid dehydrogenase and diaphorase immobilized onto alkylamine glass beads. Ind. J. Biochem. \& Biophy. 43, 2006, 98-104.

[25]. $\quad{ }^{3}$ Rani, K. Immobilization of Azadirachta Indica alkaline phosphatase onto polyethylenimine-treated chlorinated woven bombyx mori silk fabric. Int. J. Biochem Biotech. 1 (1), 2011, 1-4.

[26]. $\quad{ }^{4}$ Rani, K. Comparative study of kinetic parameters of bacterial and fungal amylases. J. Innov. 1(3), 2012, 4857.

[27]. Rodriguez-Fernandez, J., Berasategui, A. and Villafafila, Role of Bivalent Cations on the Catalytic Properties of an Extracellular Lipase of Pseudomonas fluorescens. Lebensmittel- Wissenschaft undTechnologie. 26, 1993, 422-425.

[28]. Taylor, R.F. Commercially available supports for protein immobilization. Bioprocess Technol. 14, 1991, 139-160.

[29]. Tsukura, T; New utilization technology of silk protein biomaterial. J. Technol. Rex Minist. Agric. Forest. \& Fish. Jpn. 14(11) 1991, 3-28.

[30]. Villeneuve, P., Muderhwa, J.M. and J. Graille, M.J. Haas, Customizing lipases for biocatalysis: a survey of chemical, physical and molecular biological approaches. J Mol Catalysis B: Enz. 9, 2000, 113-148.

[31]. Yomo, H. and Varner, J. E. in Current Topics in Developmental Biology, eds A. A. Moscena and A. Monray (New York: Academic Press), (1971); Vol. 6, p. 21.

Table1. Kinetic parameters of immobilized Vigna radiate $\beta$-amylase on to sodium nitrate treated chlorinated woven Bombyx 
IOSR Journal of Pharmacy

Vol. 2, Issue 3, May-June, 2012, PP.512-519

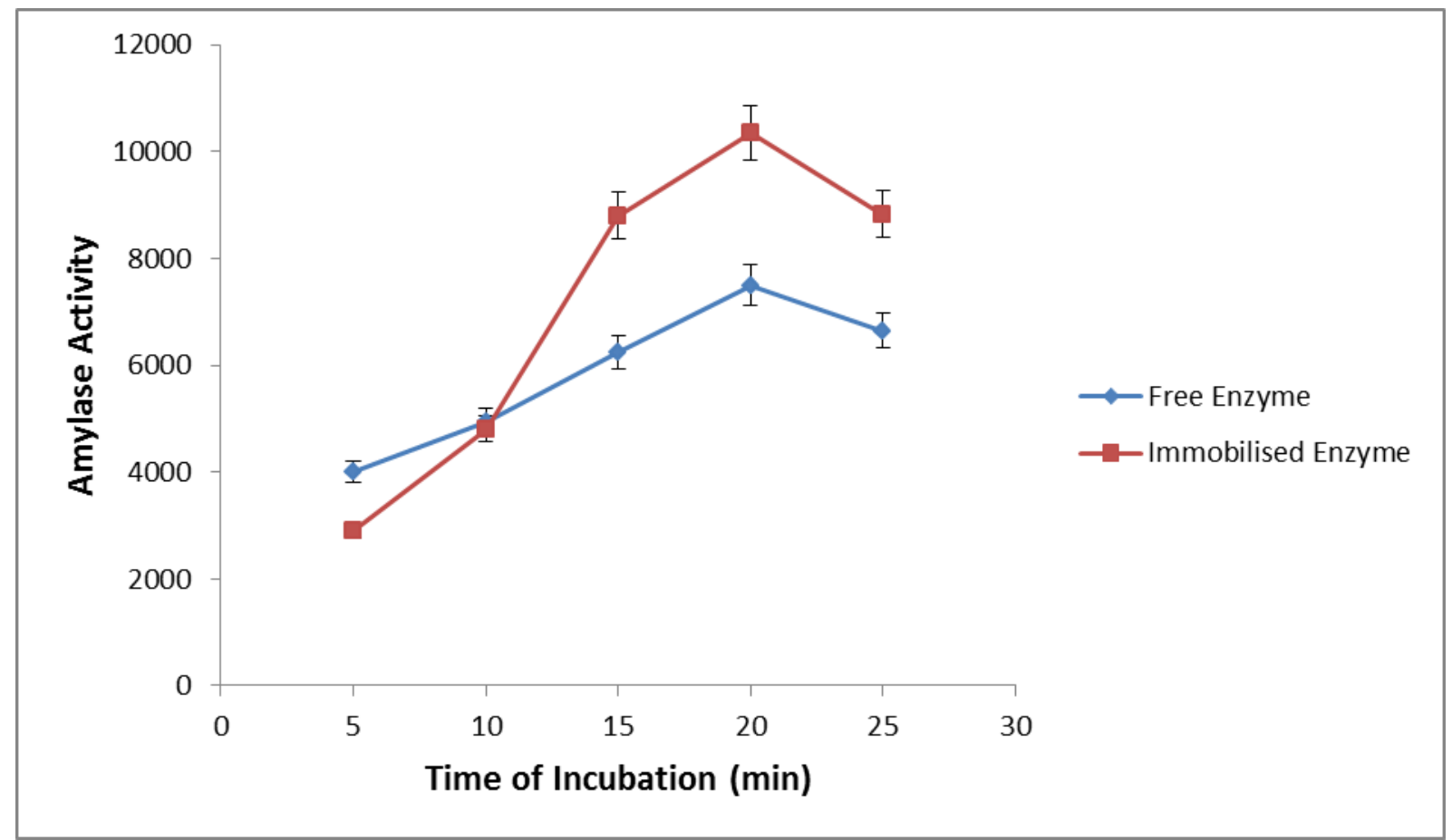

\section{Graphs}

Fig.1 Effect of incubation time on activity of free and immobilized Vigna radiata $\beta$-amylase.

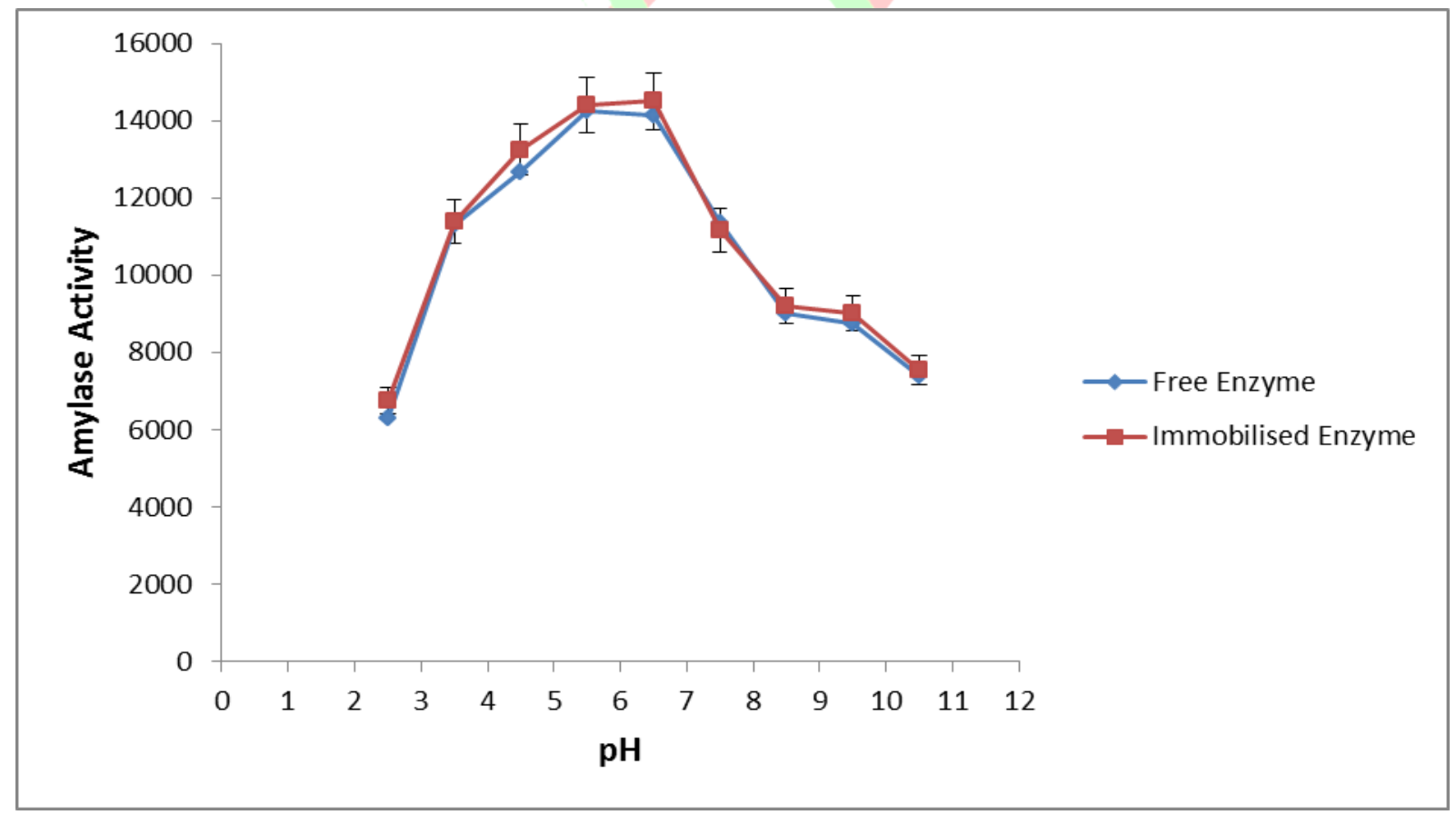

Fig.2 Effect of $\mathrm{pH}$ on activity of free and immobilized Vigna radiata $\beta$-amylase 
IOSR Journal of Pharmacy

Vol. 2, Issue 3, May-June, 2012, PP.512-519

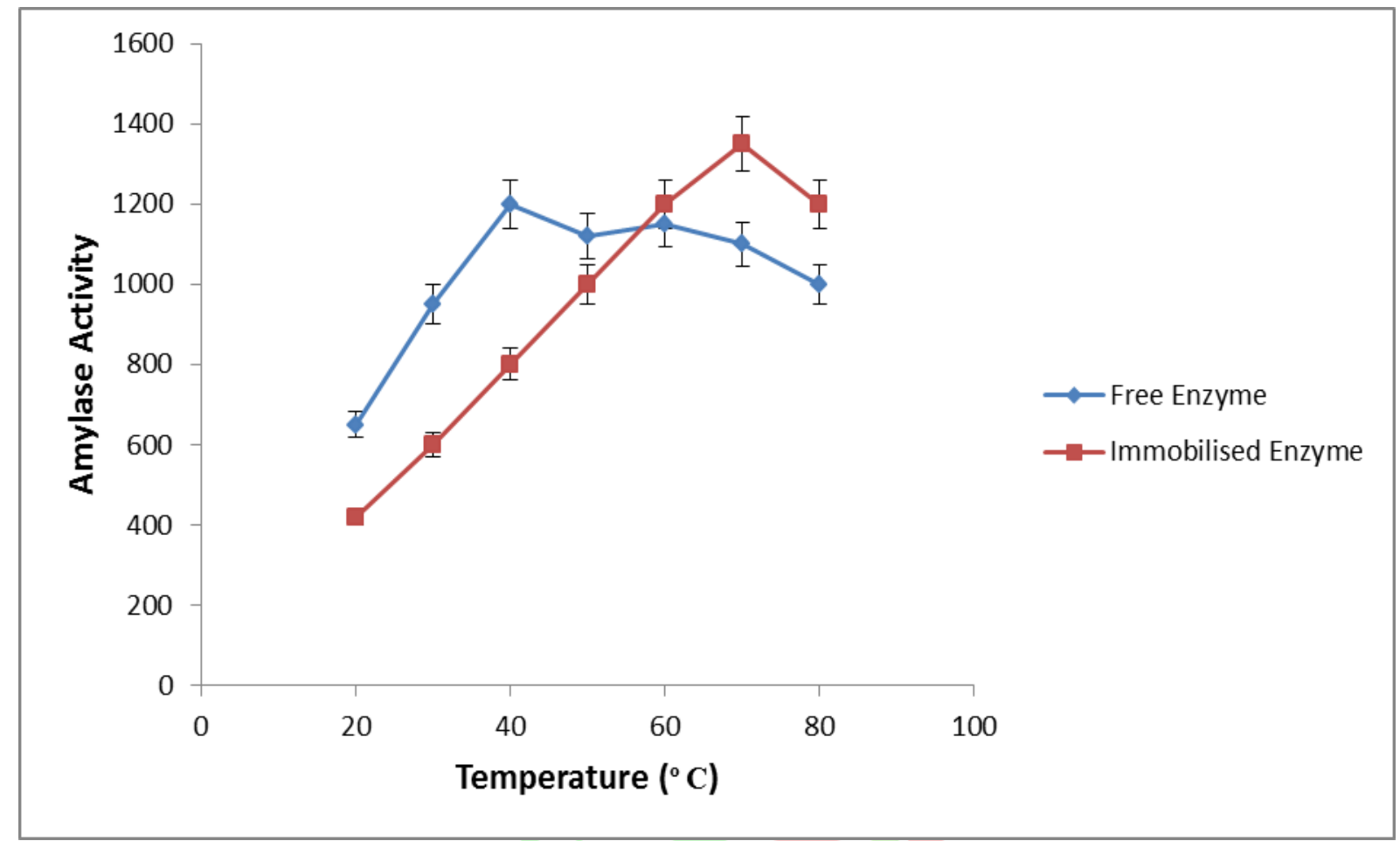

Fig.3:Effect of temperature on activity of free and immobilized Vigna radiata $\beta$-amylase.

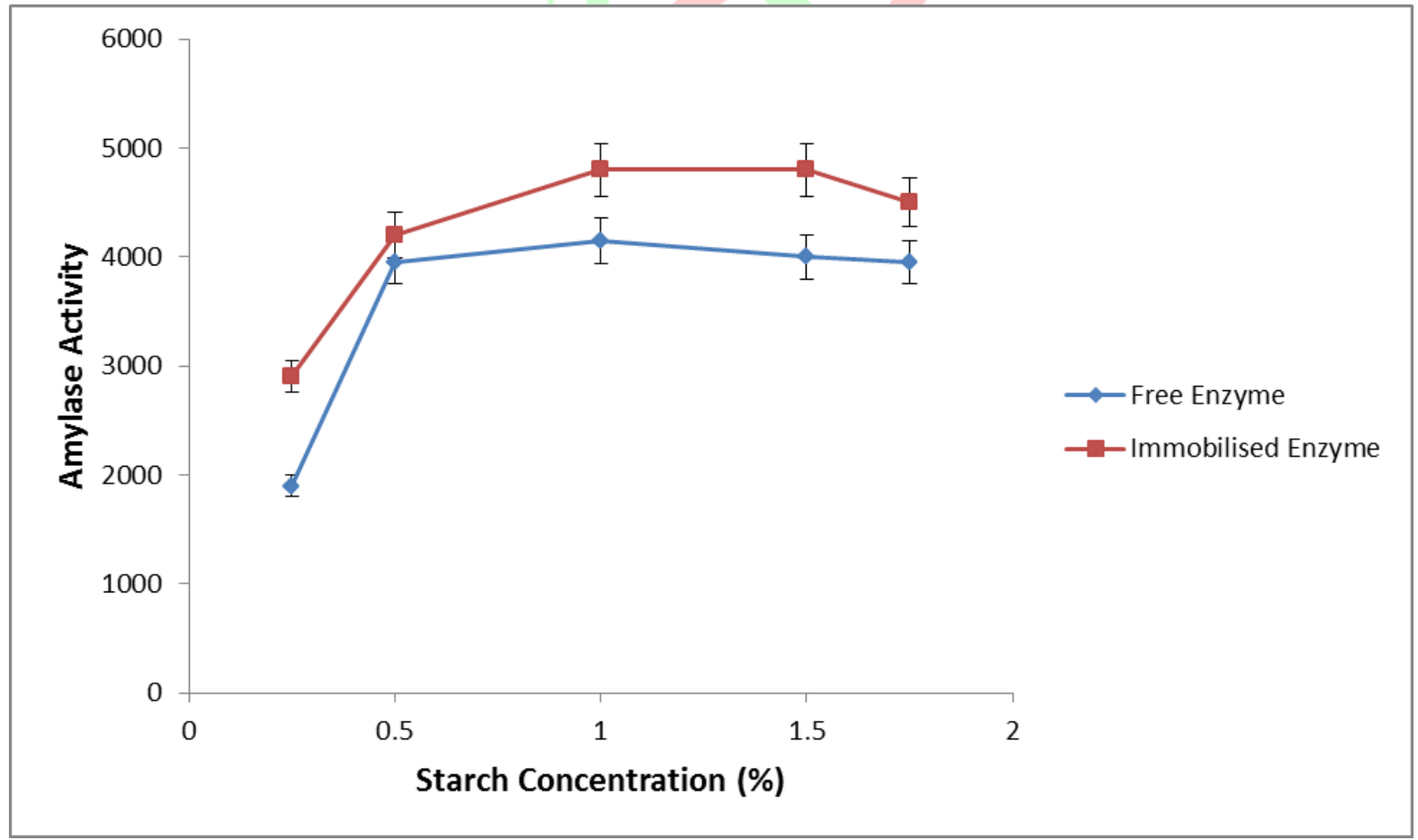

Fig.4:Effect of substrate concentration on activity of free and immobilized Vigna radiata $\beta$-amylase. 
IOSR Journal of Pharmacy

Vol. 2, Issue 3, May-June, 2012, PP.512-519

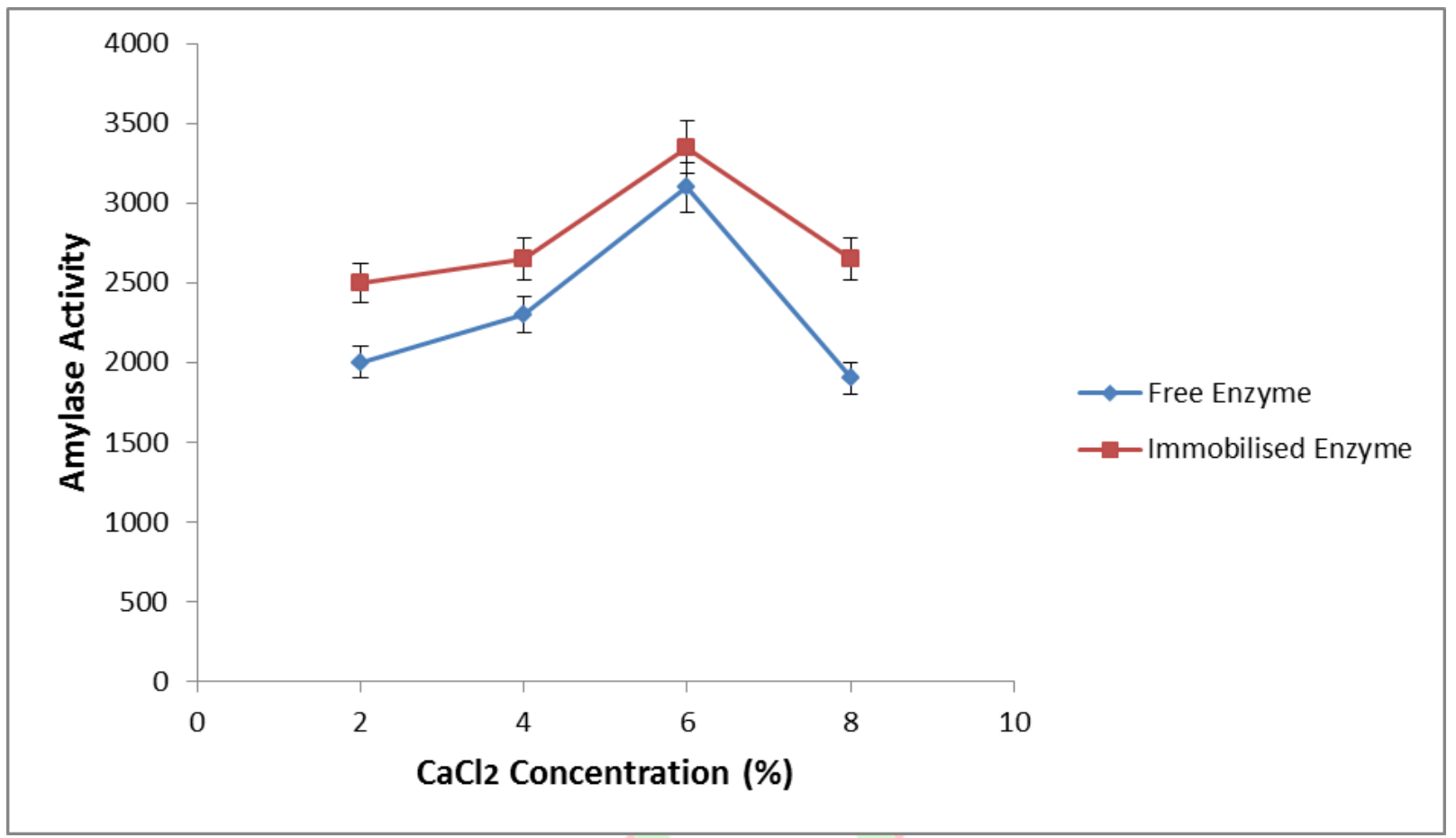

Fig.5:Effect of $\mathrm{CaCl}_{2}$ concentration on activity of free and immobilized Vigna radiata $\beta$-amylase.

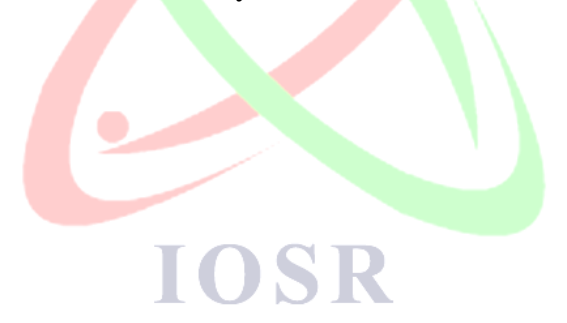

